\title{
The sender-receiver relationship as moderator of the persuasive effect in polysemic communication ${ }^{1}$
}

According to Camden, Motley and Wilson $(1984)^{2}$ polysemous communication, mainly due to the higher degree of social acceptance of allusions and semitruths (than of overtly stating untruth), constitutes, from the sender-receiver perspective, an interesting communication strategy which we fall back upon in hope of diverse social benefits: acquiring the acceptance of others, improving one's self-assessment, or reducing dissonance, protecting one's own interests (e.g. when we do not reveal other sources of income), or simply avoiding the potentially negative consequences of our own words. The above realisation, as well as the strategic and image-related benefits resulting from polysemous communication, particularly if a sender's message is to reach various receiver groups and each receiver is supposed to find something for herself/himself in it, naturally also raises questions regarding the costs incurred in the sender-receiver relationship. Is polysemous communication cost-efficient and for whom? How is the sender of

* M.A., e-mail: karolina.dobrosz@uni.lodz.pl; Chair of Journalism and Social Communication, Faculty of Philology, University of Lodz.; M.A., e-mail: zet-zet@zet-zet.com.pl; Chair of Journalism and Social Communication, Faculty of Philology, University of Lodz.

${ }^{1}$ The article was developed within a research project financed by the subsidy for young scientists in 2016, and constitutes a supplement to the study of the influence of cognitive polysemy on the persuasive effect published in: K. Dobrosz-Michiewicz, "Wieloznaczność poznawcza jako strategia komunikacyjna", Acta Universitatis Lodzensis. Folia Litteraria Polonica, 2017 [in press]. The related analyses showed that even though polysemy in communication constitutes a type of inhibitor of opposition on the part of receivers in relation to the content being communicated, the principle is not applicable for communicating in the case of previously polarised receiver attitudes (thus polysemy is a strategy for maintaining the status quo, which can neither be used to convince the unconvinced nor discourage those favourable to us) (conclusion 1); the co-existence of messages operating at various levels of ambiguity is a limitation for applying polysemy as a communication strategy used for persuasive effect (conclusion 2); the presence of a message which utilises basic level polysemy in a message diminishes the influence of higher level polysemy on the persuasive effect achieved by the message (conclusion 3); attitudes shaped by messages which operate at a higher level of conceptualisation of polysemy are less resistant to change (conclusion 4).

${ }^{2}$ Cf. C. Camden, M.T. Moltey, A. Wilson, "White lies in interpersonal communication: A taxonomy and preliminary investigation of social motivations", Western Journal of Speech Communication 1984, Issue 48 (4), pp. 309-325. 
a polysemous message evaluated by his receivers? Does she/he lose or gain credibility? Is she/he considered less competent or are her/his competences valued more by the receivers? Are the receivers more willing to agree with monosemous communicators, or is it easier to gain the agreement of the receivers through polysemous communication? And finally, does the polysemous nature of a message have any influence on its persuasive effect? If so, what are the functional limitations for applying polysemy in communication from the perspective of the senderreceiver relationship?

\section{Language-induced cognitive polysemy}

In the search of answers to the above questions, for the purpose of this study, we planned and executed a series of quasi-experimental studies, the aim of which was to define how polysemy manifested in a text translates into the evaluation of the sender of a polysemous message, thus how it moderates the persuasive effect achieved using the message. In these studies, we used the cognitive polysemy construct (independent variable) developed on the basis of cognitive analyses of politicians' communications ${ }^{3}$.

The notion of polysemy in communication is discussed from the perspective of cognitive semantics and grammar (i.e. more broadly than at only the level of the linguistic system, considering the creativity, memory, and the imagination of the communicating entities: as a result of rejecting the assumption that meanings are established in the language, acute and clear, and limited by the scopes of their categories, and accepting the assumption that our thinking is naturally vague, ambiguous and ever-changing), and studied using methods applicable for social sciences (also outside the linguistic system, in terms of sender-receiver processes, which are supported by the creativity and imagination of the communicating entities). In accordance with the principles of cognitive semantics, new meanings or amalgams form initially within the process of conceptualisation, and are only later evoked in communication through language. Additionally, by utilising the cognitive approach in the study of polysemy, we were able not only to identify and describe polysemy as a natural and inevitable component of any communication occurring through language, a consequence of the fact that the act of composing

\footnotetext{
${ }^{3}$ A detailed definition of the cognitive concept of polysemy developed based on the analyses of politicians' communication was offered in: K. Dobrosz-Michiewicz, "Struktura wieloznaczności poznawczej (na podstawie komunikowania w polityce)", Acta Universitatis Lodziensis. Folia Litteraria Polonica 2016, Issue 2 (32), pp. 187-205. For the purposes of this study (since the cognitive polysemy construct constitutes a leading and independent variable in the quasi-experimental studies presented herein), we present in the article only the main conclusions from respective analyses.
} 
meaning, though being a structured process, depends on the creativity, memory and imagination of the communicating entities ${ }^{4}$, but also, as a consequence of the above-mentioned assumption, to study polysemy using the tools available for not just one, but various sciences which together form so-called cognitive science 5 .

Category-based analyses of textual emanations of polysemy, which were the subject of previous works of the author, led to two main conclusions regarding the structure of cognitive polysemy:

1) polysemy is included in linguistic communication at various levels of conceptualisation:

a) at the basic level, when polysemy results directly from the polysemous nature of concepts which possess more than one centre and a radial structure, but a rather defined scope; then the creative role of receivers in processing information is limited by that scope); as in the case of categories: CHALLENGES, JUSTICE or FAMILY;

b) at the second level (when it constitutes the consequence of the polysemous nature of conceptual amalgams formed through the fusing of initial domains - categories for which the scope is known at least partially; then the role of the creativity of the receivers in processing information expands); as in the case of amalgams DEMOGRAPHIC CRISIS, POLAND'S WELL-BEING or THE SEA'S POTENTIAL;

c) we can also encounter in communication the so-called higher level polysemy, using amalgams formed by fusing polysemous categories or categories the scope of which is unknown - then the role of the receiver's creativity in processing information is only limited by the limitations of her/his perception); as in the case of the amalgams GOOD CHANGE or ACTIVATION OF THE GREAT RESERVE.

${ }^{4}$ According to R. Langacker, our mental conviction is always coherent because it is us who assign it structure. Thus the only limitation on polysemy would be the limitations of human cognition. Langacker posited that "The basic element of the ability to structure is the interpretation of new experiences based on existing ones which are considered within the categories of asymmetry between the standard of comparison and the target of comparison [...]. Our existing experiences take the form of a well-entrenched path activated within the process of structuring specific observations (e.g. in the case of recognising specific shapes). Cf. R.W. Langacker, "Wykłady z gramatyki kognitywnej”, H. Kardela, P. Łozowski (eds.), transl. by A. Głaz, K. Wengorek-Dolecka, Wydawnictwo Uniwersytetu Marii Curie-Skłodowskiej, Lublin 2005.

${ }^{5}$ Extensive discussions of the topic were offered by the following classical works in cognitive semantics and grammar: G. Lakoff, M. Johnson, "Metafory w naszym życiu" [Methaphors We Live By], transl. by P. Krzeszowski, Warsaw 1988; R.W. Langacker, op. cit.; J.R. Taylor, "Kategoryzacja w języku. Prototypy w teorii językoznawczej”, transl. By A. Skucińska, Towarzystwo Autorów i Wydawców Prac Naukowych Universitas, Cracow 2001; E. Tabakowska, "Gramatyka i obrazowanie. Wprowadzenie do językoznawstwa kognitywnego", Polska Akademia Nauk, Warsaw 1995. 
All the textual manifestations of polysemy quoted herein as well as the communication used for experiment priming came from political texts: speeches by former Prime Minister Ewa Kopacz and current Prime Minister Beata Szydło. By analysing their programme speeches, we were able to identify pairs of: category (political aim) - category scope (how it is understood, how it will be achieved), which then, in line with the principles of cognitive semantics and grammar, we analysed in a study Struktura wieloznaczności poznawczej, and used it for further empirical studies, the results of which we present herein.

\section{Experimental study of the evaluation of the sender of a polysemous message}

The quasi-experimental two-stage study conducted in May-June on the students of the University of Lodz $(\mathrm{N}=160)$ selected at random aged 20-24, consisted of:

- a quasi-experimental part where the subjects were assigned at random to one of two experimental groups, they were asked to read a text which included higher level polysemy (group 1) or a text which included basic level polysemy (group 2); group 1 was assigned a highly polysemous communication, i.e. marked with higher level polysemy and amalgams (FUTURE CHALLENGES; GROWTH RATE; ECONOMIC SPHERE; SOCIAL RIGHTS SPHERE; STATE OF THE COUNTRY, NEGATIVE PHENOMENA, POSITIVE PHENOMENA):

We must face the challenges of the future. And those are clear. We must break loose from the trap of medium growth. That means increasing the growth rate. Accept the solutions to all the problems we face within the spheres of the economy, social issues, and the state of the country. Regarding its domestic and international status. The statuses of the economy, social issues, and the country are not at the level of actual divergent social processes. On the contrary. They are related to one another regardless of whether negative or positive phenomena emerge. In the case of the latter, we may achieve synergy. Mutual amplification of positive processes.

Group 2 was assigned a paraphrase of message A with a lowered polysemous load (basic level polysemy) in relation to the original, in which for some of the amalgams which constituted the components of text A, the original scope of at least one initial space was defined, usually by defining the scope of the monosemous category: 
We must face the challenges of the future, i.e. the coming 4 years. And those are clear. We must break loose from the trap of medium growth. That means we must increase the growth rate by at least 3-4\% GDP. Accept the solutions of all the problems we face in terms of the economy (support for entrepreneurs), social issues (support families and the poorest, a housing programme), and the condition of the country (improve the administration). Regarding its domestic and international status. The statuses of the economy, social issues, and the country are not at the level of actual divergent social processes. On the contrary. They are related to one another both when there emerge negative phenomena, when the economic crisis means impoverishment of the citizens, and positive when the improvement of the economic situation translates into increasing affluence. In the case of the latter, we may achieve synergy. Mutual amplification of positive processes.

- a survey study in which respondents evaluated the credibility and the competences of the sender of a message, independently in both groups, on a scale in relation to:

1) sender credibility evaluated according to a Likert scale from 1 (very low) to 5 (very high);

2) sender competences evaluated according to a Likert scale from 1 (very low) to 5 (very high).

On separate sheets, upon completing the evaluation of sender credibility and competences (considering the influence of prior events and attributive processes), the subjects also defined to what extent:

3) they agree with the sender, based on a scale from 1 (strongly disagree) to 5 (strongly agree);

4) the evaluated message is polysemous (on a scale: from 1 when the message was monosemous to 5 when it was polysemous);

5) and they defined their political preferences at two time points: currently and during the last parliamentary election.

The data collected in point 4 enabled us to verify to what extent the study results depended on respondents' realisation, or a lack of it, of the polysemy of a message, while the data collected in point 5 enabled us to verify to what extent the study results varied in the case of constancy or changeability of one's political preferences. The relationship between the study results, and political views and their changes is the subject of analysis within the framework of a separate study. To enable an evaluation of to what extent the results depended on the level of the receiver's identification of a message's polysemy, the collected data were analysed in subgroups (divided depending on the degree to which the respondents identified the polysemy of a message: subgroup 1: result on a scale $<3$; subgroup 2 : result on a scale $>3$. 
The study results have basically led to 4 conclusions in terms of the functional limitations of the application of polysemy in communication (from the point of view of the evaluation of a sender of a polysemous message):

1) a message with a stronger polysemous markedness generated among respondents a higher agreement with the sender;

2) the sender of a more polysemous message was evaluated as more credible;

3) the level of polysemous markedness of a message was irrelevant for the evaluation of the competences of its sender;

4) both for the evaluation of the agreement with the sender, and her/his credibility and competences, the level of the receivers' awareness in terms of the message's polysemy was irrelevant; however, the influence of credibility and the evaluation of competences on the agreement with the sender was significant.

\section{The higher the level of conceptualisation of a polysemous message, the higher the agreement among the receivers with the content being communicated (?)}

The comparison of the results in both groups clearly confirmed that a message marked with higher level polysemy (HLP) evoked higher agreement among the receivers than a message marked with basic level polysemy (BLP) regardless of whether the subjects were (1) aware of the polysemous nature of the message $(\mathrm{N}=93)$ or $(2) \operatorname{not}(\mathrm{N}=67)$.

Figure 1. Evaluation of the agreement with the sender of a message in relation to the level of its polysemy within the study group (1), members of which classified its polysemy at $>3(\mathrm{~N}=93)$, and those who classified its polysemy at $>3(\mathrm{~N}=67)$.

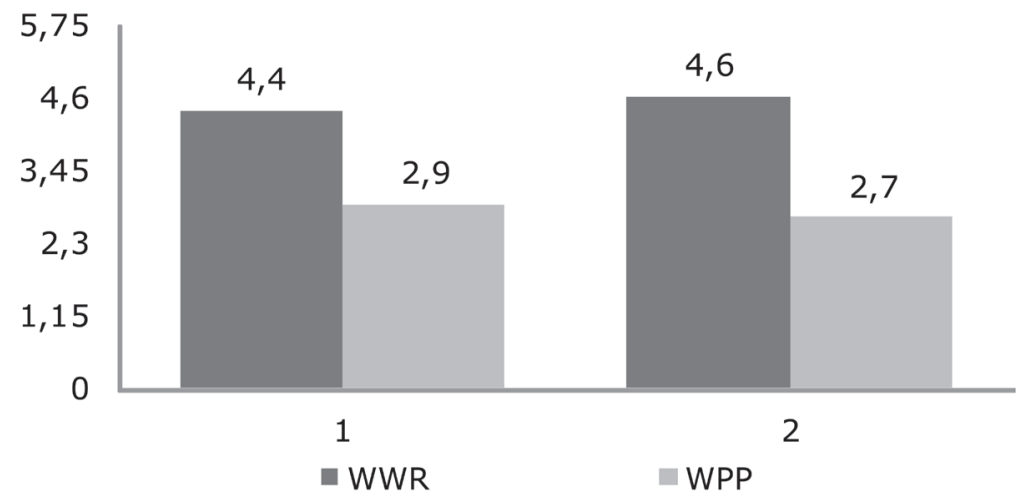

Source: own study. 


\section{The higher the level of conceptualisation of a polysemous message, the more credible its sender is (?)}

The sender was evaluated as considerably more credible yet similarly competent in the case of a message highly marked with polysemy, both in the group of subjects who were aware of the polysemous nature of the message and those who were not.

Figure 2. Evaluation of the credibility of the sender of a message in relation to the level of its polysemy within the study group (1), members of which classified its polysemy at $>3(\mathrm{~N}=93)$, and those who classified its polysemy at $>3(\mathrm{~N}=67)$

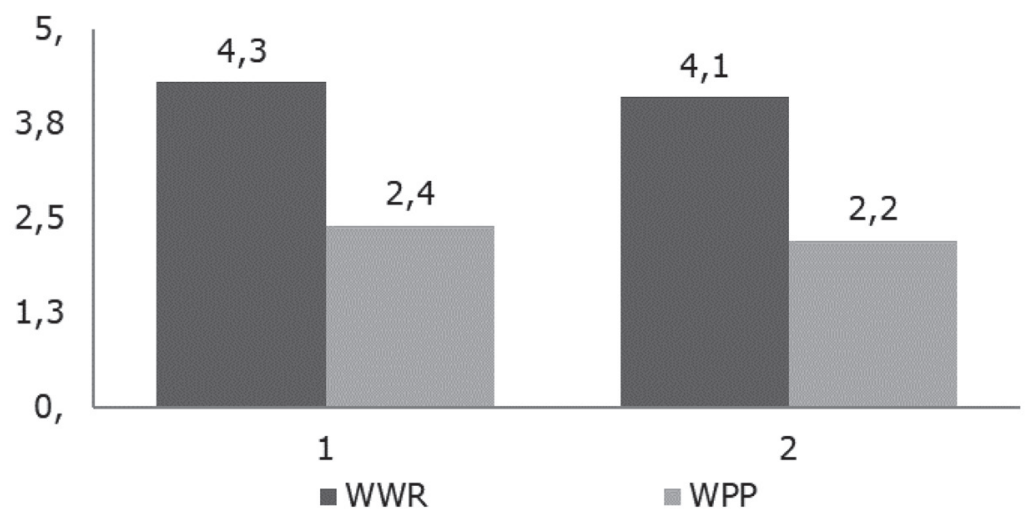

Source: own study.

Figure 3. Evaluation of the competences of the sender of a message in relation to the level of its polysemy within the study group (1), members of which classified its polysemy at $>3(\mathrm{~N}=93)$, and those who classified its polysemy at $<3(\mathrm{~N}=67)$

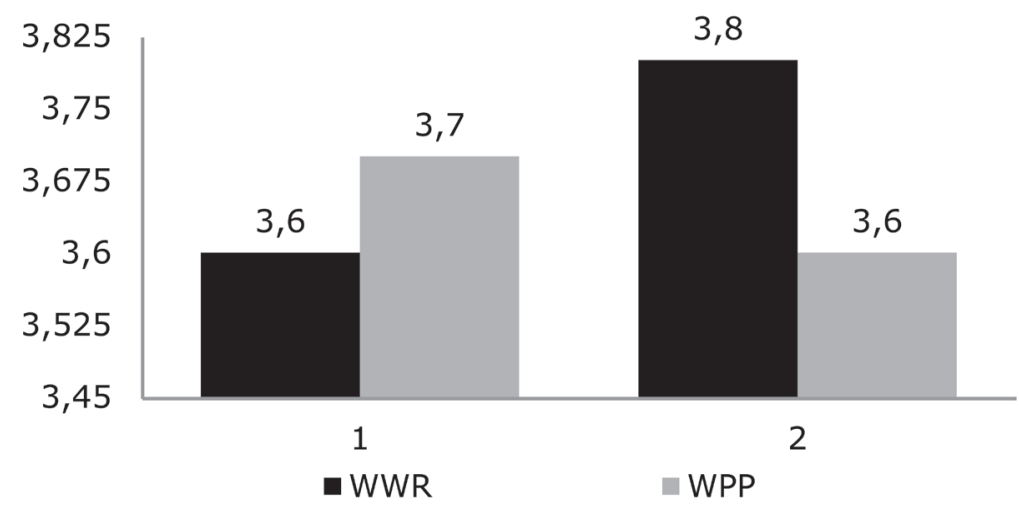

Source: own study. 


\section{Level of polysemy conceptualisation vs. the evaluation of the competences of the sender of a polysemous message}

The analysis of the relationship between the study variables (agreement with the sender, evaluation of a sender's credibility, evaluation of sender's competences) revealed that though the correlations between the identified polysemous nature of a message and the agreement with it were not statistically significant, the correlations between the sender's credibility and the agreement was higher than between the agreement and the evaluation of the competences, both for messages which included basic level polysemy $(r=0.58$ and $r=0.44$ respectively) and higher level polysemy $(r=0.53$ and $r=0.46$ respectively).

\section{Conclusion}

In view of the results discussed herein, polysemous communication seems to offer a speaker more benefits than any potential losses. Saturating a text with polysemy, regardless of the degree to which the receiver realises its presence, may, in fact, lead to increased credibility of the sender and the receiver's agreement with the sender, while at the same time remaining irrelevant for the evaluation of her/his competences. What mechanisms lie at the foundation of the above limitation of the functions of communication through polysemy?

That which links the evaluation of credibility to agreement with the sender, and, at the same time, differentiates it from the evaluation of her/his competences, is the referral to the standards of the receiver's $I$ in the decision process (in the first two cases). In order to answer the question how much do you agree/trust, the receiver compares that which is external with that which is personal and internal (the above component is missing from the evaluation of the competences of the receiver who is external in relation to the sender). Shifting the decision-making processes onto a meta-cognition level enables a series of egotistic mechanisms, which are strong, automatic, and adaptive ${ }^{6}$. Thus, attention processes focus more on processing the data related to the $I$ than data originating from the outside (the message). The mind, additionally supported by the attributive tendencies of thinking, supplements the denotation-deficient message with content of its own cognition as posited by Langacker ${ }^{7}$, which is

\footnotetext{
${ }^{6}$ Cf. K. Dobrosz-Michiewicz, "Dialogowość komunikatów perswazyjnych", in: "Badanie i projektowanie komunikacji 3", M. Wszołek (ed.), Wydawnictwo Libron, Wroclaw 2014.

${ }^{7}$ R.W. Langacker, op. cit., p. 74.
} 
why it seems irrelevant whether the receiver realises or not the polysemous nature (she/he substitutes within the reception process the data missing from the message with data originating from her/his own experience, i.e. memorybased).

\section{Bibliography}

Camden C., Moltey M.T., Wilson A., "White lies in interpersonal communication: A taxonomy and preliminary investigation of social motivations", Western Journal of Speech Communication 1984, Issue 48 (4), pp. 309-325.

Dobrosz-Michiewicz K., "Struktura wieloznaczności poznawczej (na podstawie komunikowania w polityce)", Acta Universitatis Lodziensis. Folia Litteraria Polonica 2016, Issue 2 (32), pp. 187-205.

Dobrosz-Michiewicz K., "Wieloznaczność poznawcza jako strategia komunikacyjna”, Acta Universitatis Lodzensis. Folia Litteraria Polonica, 2017 [in press].

Dobrosz-Michiewicz K., "Dialogowość komunikatów perswazyjnych”, in: "Badanie i projektowanie komunikacji 3”, M. Wszołek (ed.), Wydawnictwo Libron, Wroclaw 2014.

Lakoff G., Johnson M., "Metafory w naszym życiu” [Methaphors We Live By], transl. by P. Krzeszowski, Warsaw 1988.

Langacker R.W., "Wykłady z gramatyki kognitywnej”, H. Kardela, P. Łozowski (eds.), transl. by A. Głaz, K. Wengorek-Dolecka, Wydawnictwo Uniwersytetu Marii Curie-Skłodowskiej, Lublin 2005.

Tabakowska E., "Gramatyka i obrazowanie. Wprowadzenie do językoznawstwa kognitywnego", Polska Akademia Nauk, Warsaw 1995.

Taylor J.R., "Kategoryzacja w języku. Prototypy w teorii językoznawczej”, transl. by A. Skucińska, Towarzystwo Autorów i Wydawców Prac Naukowych Universitas, Cracow 2001.

Karolina Dobrosz-Michiewicz, Zofia Władyka-Łuczak

\section{The sender-receiver relationship as moderator of the persuasive effect in polysemic communication}

\section{(Summary)}

The article presents the results of an empirical experimental study into the functional aspects of polysemous communication in politics. The analyses of the results have led to the following conclusions in terms of the functional limitations of the application of polysemy in communication (from the point of view of the evaluation of a sender of a polysemous message):

a message with a stronger polysemous markedness generated a higher agreement with the sender among respondents,

the sender of a more polysemous message was evaluated as more credible,

the level of polysemous markedness of a message was irrelevant for the evaluation of the competences of its sender, 
both for the evaluation of the agreement with the sender, and her/his credibility and competences, the level of the receivers' awareness in terms of the message's polysemy was irrelevant; however, the influence of credibility and the evaluation of competences on the agreement with the sender was significant.

Keywords: cognitive polysemy, limitations of polysemous communication, communication in politics, polysemy and sender's credibility, polysemy and sender's competences. 